\title{
Alishewanella aestuarii sp. nov., isolated from tidal flat sediment, and emended description of the genus Alishewanella
}

Correspondence Jin-Woo Bae baejw@kribb.re.kr

\author{
Seong Woon Roh, ${ }^{1,2}$ Young-Do Nam, ${ }^{1,2}$ Ho-Won Chang, ${ }^{2}$ \\ Kyoung-Ho Kim, ${ }^{2}$ Min-Soo Kim, ${ }^{1,2}$ Hee-Mock $\mathrm{Oh}^{2}$ and Jin-Woo Bae ${ }^{1,2,3}$ \\ ${ }^{1}$ University of Science \& Technology, 52, Eoeun-dong, Daejeon 305-333, Republic of Korea \\ ${ }^{2}$ Biological Resource Center, KRIBB, Daejeon 305-806, Republic of Korea \\ ${ }^{3}$ Environmental Biotechnology National Core Research Center, Gyeongsang National University, \\ Jinju 660-701, Republic of Korea
}

A Gram-negative strain, $\mathrm{B} 11^{\top}$, was isolated from tidal flat sediment in Yeosu, Republic of Korea. Strain $\mathrm{B} 11^{\top}$ did not require $\mathrm{NaCl}$ for growth and grew between 18 and $44^{\circ} \mathrm{C}$. Phylogenetic analysis based on $16 \mathrm{~S}$ rRNA gene sequences showed that strain $\mathrm{B} 11^{\top}$ was associated with the genus Alishewanella and was closely related to the type strain of Alishewanella fetalis (98.3\% similarity). Within the phylogenetic tree, the novel isolate shared a branching point with $A$. fetalis. Analysis of $16 \mathrm{~S}$ rRNA gene sequences and DNA-DNA relatedness, as well as physiological and biochemical tests, indicated genotypic and phenotypic differences between strain $\mathrm{B} 11^{\top}$ and the type strain of $A$. fetalis. Thus, strain $\mathrm{B} 11^{\top}$ is proposed as a representative of a novel species, Alishewanella aestuarii sp. nov.; the type strain is $B 11^{\top}\left(=\operatorname{KCTC} 22051^{\top}=\mathrm{DSM} 19476^{\top}\right)$.
The genus Alishewanella, proposed by Fonnesbech Vogel et al. (2000), belongs to the class Gammaproteobacteria. Currently, Alishewanella fetalis is the only species within the genus and it was first isolated from an autopsy of a human fetus in Sweden. Here, strain $\mathrm{B} 11^{\mathrm{T}}$, a representative of another Alishewanella species, was isolated from a marine environment and characterized.

Strain $\mathrm{B} 11^{\mathrm{T}}$ was isolated from tidal flat sediment in Yeosu ( $\left.34^{\circ} 47^{\prime} 26^{\prime \prime} \mathrm{N} 127^{\circ} 34^{\prime} 01^{\prime \prime} \mathrm{E}\right)$, Republic of Korea. The strain was isolated on R2A agar (Difco) followed by repeated restreaking to obtain a pure culture. The Gram reaction was determined according to the non-staining method described by Buck (1982). Cell morphology was examined by light microscopy (ECLIPSE $80 i$; Nikon) and electron microscopy. R2A broth was used to examine growth under various $\mathrm{NaCl}$ concentrations and temperature conditions. Growth on tryptic soy agar (TSA; Difco), marine agar (MA; Difco), nutrient agar (NA; Difco), Luria agar (LA; Difco) and blood agar containing 5\% sheep blood was also determined. Starch hydrolysis was performed as described by Smibert \& Krieg (1994). Catalase activity was determined by observing bubble production in a $3 \%(\mathrm{v} / \mathrm{v})$ hydrogen peroxide solution. Enzyme activities and substrate utilization from sole carbon sources were determined using the API 20NE and API ZYM test strips (bioMérieux). Some of these results are given in the species

The GenBank/EMBL/DDBJ accession number for the 16S rRNA gene sequence of strain $B 11^{\top}$ is EF660759. description; Table 1 shows a comparison between the characteristics of strain $\mathrm{B} 11^{\mathrm{T}}$ and closely related strains.

Chromosomal DNA was extracted and purified using a DNA extraction kit (IntronBiotechnology). The $\mathrm{G}+\mathrm{C}$ content was determined using HPLC as described by Mesbah \& Whitman (1989). The 16S rRNA gene was amplified by PCR from chromosomal DNA using two universal primers for bacteria (Baker et al., 2003). The PCR product was purified and sequencing was performed using the BigDye Terminator Cycle Sequencing Ready Reaction kit (Applied Biosystems), according to the manufacturer's instructions. Reaction mixtures were analysed using an automated DNA analyser system (PRISM 3730XL DNA analyser; Applied Biosystems). Full-length 16S rRNA gene sequences were assembled using SEQMAN software (DNASTAR). 16S rRNA gene sequences from the novel isolate and related taxa (obtained from the NCBI database) were aligned using the multiple sequence alignment program CLUSTAL_X 1.8 (Thompson et al., 1997). Pairwise $16 \mathrm{~S}$ rRNA gene sequence similarities were determined using the WATER program in EMBOss (Rice et al., 2000). Phylogenetic relationships between representative species in the phylogenetic neighbourhood were determined using the programs MEGA3 (Kumar et al., 2004) and PAUP 4.0 (Swofford, 1998). Distance matrices were determined (Kimura, 1980) and used to elaborate dendrograms by the neighbour-joining (Saitou \& Nei, 1987), maximumparsimony (Kluge \& Farris, 1969) and maximum- 
Table 1. Differential characteristics of strain $B 11^{\top}$ and type strains of closely related species

Strains: 1, Alishewanella aestuarii sp. nov. B11 ${ }^{\mathrm{T}}$; 2, A. fetalis CCUG $30811^{\mathrm{T}}$ (data from Fonnesbech Vogel et al., 2000); 3, R. aquimaris SW-353 (Yoon et al., 2007); 4, R. pacifica CCUG $46544^{\mathrm{T}}$ (Romanenko et al., 2003); 5, R. perlucida BA131 ${ }^{\mathrm{T}}$ (Brettar et al., 2006). Data for nitrate reduction and hydrolysis and assimilation tests are from the API 20NE test system. +, Positive; -, negative; (-), weak or negative reaction; NR, not reported; PNPG, $p$-nitrophenyl $\beta$-D-galactopyranoside.

\begin{tabular}{|c|c|c|c|c|c|}
\hline Characteristic & 1 & 2 & 3 & 4 & 5 \\
\hline Motility & + & - & + & + & + \\
\hline \multicolumn{6}{|l|}{ Growth at/in: } \\
\hline $20^{\circ} \mathrm{C}$ & + & - & + & + & + \\
\hline $0 \% \mathrm{NaCl}$ & + & - & + & + & + \\
\hline $8 \% \mathrm{NaCl}$ & - & + & + & + & + \\
\hline Temperature range for growth $\left({ }^{\circ} \mathrm{C}\right)$ & $18-44$ & $25-42$ & $4-43$ & $4-37$ & $4-37$ \\
\hline Nitrate reduction to nitrite & + & + & + & - & + \\
\hline$\beta$-Glucosidase (aesculin hydrolysis) & - & + & + & + & + \\
\hline$\beta$-Galactosidase (PNPG hydrolysis) & - & - & $\mathrm{NR}$ & + & - \\
\hline \multicolumn{6}{|l|}{ Assimilation of: } \\
\hline Glucose & - & - & + & - & - \\
\hline Arabinose & - & - & - & + & - \\
\hline$N$-Acetylglucosamine & - & - & + & + & + \\
\hline Maltose & + & $(-)$ & + & + & - \\
\hline Trisodium citrate & - & - & - & + & - \\
\hline DNA G $+C$ content $(\mathrm{mol} \%)$ & 49.5 & 51.0 & 50.5 & 49.6 & 48.9 \\
\hline Isolation source & Tidal flat sediment & Human fetus & Seawater & Seawater & Seawater \\
\hline
\end{tabular}

likelihood (Felsenstein, 1981) methods. To evaluate the stability of the trees, a bootstrap analysis was performed using a consensus tree based on 1000 randomly generated trees. The $16 \mathrm{~S}$ rRNA gene sequence of strain $\mathrm{B} 11^{\mathrm{T}}$ was compared with sequences of reference strains of species belonging to the class Gammaproteobacteria. Fig. 1 indicates that strain $\mathrm{B} 11^{\mathrm{T}}$ is affiliated phylogenetically with A. fetalis; this affiliation is supported by high bootstrap values $(100,98$ and $94 \%$ by the neighbour-joining, maximum-parsimony and maximum-likelihood methods, respectively). Similarities between the $16 \mathrm{~S}$ rRNA gene

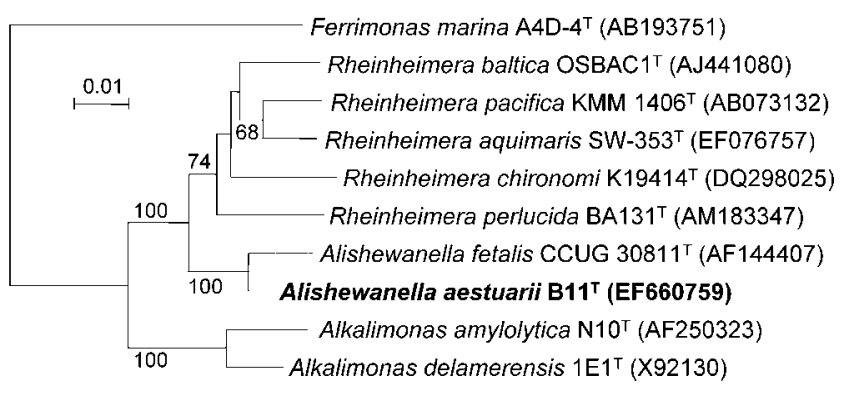

Fig. 1. Phylogenetic tree based on 16S rRNA gene sequences. The position of strain $B 11^{\top}$ is shown with respect to strains of related species. The tree was generated using the neighbourjoining method. Numbers at nodes indicate bootstrap values (expressed as percentages of 1000 replications); values greater than $50 \%$ are shown. Bar, 0.01 accumulated changes per nucleotide. sequence of strain $\mathrm{B} 11^{\mathrm{T}}$ and those of $A$. fetalis CCUG $30811^{\mathrm{T}} \quad$ Rheinheimera aquimaris $\mathrm{SW}-353^{\mathrm{T}}$ and Rheinheimera perlucida $\mathrm{BA} 131^{\mathrm{T}}$ were 98.3, 96.5 and $96.4 \%$, respectively. A DNA-DNA hybridization experiment was performed as described previously (Roh et al., 2008); the mean DNA-DNA relatedness value between the isolate and $A$. fetalis CCUG $30811^{\mathrm{T}}$ was $47.0 \%$. The $16 \mathrm{~S}$ rRNA gene sequence similarities and the DNA-DNA relatedness value of less than $70 \%$ (Wayne et al., 1987) indicate that the isolate represents a distinct genospecies.

For quantitative analysis of cellular fatty acids, strain $\mathrm{B} 11^{\mathrm{T}}$ and $A$. fetalis CCUG $30811^{\mathrm{T}}$ were grown under the same conditions on blood agar plates at $30{ }^{\circ} \mathrm{C}$ for 2 days. Cells were harvested and cellular fatty acids were saponified, methylated and extracted as described by the Sherlock Microbial Identification System (MIDI, 1999). Fatty acids were analysed by GC (Hewlett Packard 6890) and identified using the Microbial Identification software package (Sasser, 1990). The predominant cellular fatty acids in strain $\mathrm{B} 11^{\mathrm{T}}$ were $\mathrm{C}_{18: 1} \omega 7 c, \mathrm{C}_{17: 1} \omega 8 c$, summed feature $3\left(\mathrm{C}_{16: 1} \omega 7 c\right.$ and/or iso- $\left.\mathrm{C}_{15: 0} 2-\mathrm{OH}\right), \mathrm{C}_{16: 0}$ and $\mathrm{C}_{17: 0 .}$. Complete fatty acid compositions of the novel strain and $A$. fetalis CCUG $30811^{\mathrm{T}}$ are shown in Table 2 . The fatty acid profiles of strain $\mathrm{B} 11^{\mathrm{T}}$ and the type strain of $A$. fetalis are similar. In addition to $16 \mathrm{~S}$ rRNA gene similarity, the major fatty acid components of strain $\mathrm{B} 11^{\mathrm{T}}$ and its temperature range for growth confirm affiliation of this strain with the genus Alishewanella.

In spite of the close $16 \mathrm{~S}$ rRNA gene sequence similarity between members of the genera Alishewanella and 
Table 2. Fatty acid contents (\%) of strain $\mathrm{B} 11^{\top}$ and $A$. fetalis CCUG $30811^{\top}$

Data are from this study. Both strains were grown on blood agar at $30{ }^{\circ} \mathrm{C}$ for 2 days. Values shown are percentages of total fatty acids. tr, Trace (less than $1.0 \%$ ).

\begin{tabular}{|c|c|c|}
\hline Fatty acid & Strain $B 11^{\mathrm{T}}$ & $\begin{array}{c}\text { A. fetalis CCUG } \\
30811^{\mathrm{T}}\end{array}$ \\
\hline $\mathrm{C}_{11: 0} 3-\mathrm{OH}$ & 2.2 & 1.7 \\
\hline $\mathrm{C}_{12: 0}$ & $\operatorname{tr}$ & 1.0 \\
\hline $\mathrm{C}_{12: 0} 3-\mathrm{OH}$ & 3.6 & 3.6 \\
\hline $\mathrm{C}_{14: 0}$ & $\operatorname{tr}$ & 2.1 \\
\hline $\mathrm{C}_{15: 0}$ & 1.2 & 1.9 \\
\hline $\mathrm{C}_{15: 1} \omega 8 c$ & 1.2 & $\operatorname{tr}$ \\
\hline $\mathrm{C}_{16: 0}$ & 11.0 & 14.3 \\
\hline iso- $\mathrm{C}_{16: 0}$ & 1.3 & $\operatorname{tr}$ \\
\hline $\mathrm{C}_{17: 0}$ & 8.8 & 8.6 \\
\hline $\mathrm{C}_{17: 1} \omega 6 c$ & 1.5 & $\operatorname{tr}$ \\
\hline $\mathrm{C}_{17: 1} \omega 8 c$ & 18.0 & 16.0 \\
\hline $\mathrm{C}_{18: 0}$ & 1.6 & 1.3 \\
\hline iso- $\mathrm{C}_{18: 0}$ & 1.7 & $\operatorname{tr}$ \\
\hline $\mathrm{C}_{18: 1} \omega 7 c$ & 22.6 & 17.5 \\
\hline $\mathrm{C}_{18: 1} \omega 9 c$ & 1.3 & 2.0 \\
\hline Summed feature $1^{\star}$ & 2.3 & 1.8 \\
\hline Summed feature $2^{\star}$ & 3.0 & 3.1 \\
\hline Summed feature $3^{*}$ & 11.8 & 14.9 \\
\hline
\end{tabular}

*Summed features are groups of two or three fatty acids that can not be separated using the MIDI System. Summed feature 1 comprises $\mathrm{C}_{13: 0}$ 3-OH and/or iso- $\mathrm{C}_{15: 1} \mathrm{H}$; summed feature 2 comprises unknown fatty acids; summed feature 3 comprises $\mathrm{C}_{16: 1} \omega 7 c$ and/or iso- $\mathrm{C}_{15: 0} 2-\mathrm{OH}$.

Rheinheimera, the two genera are divided with a high bootstrap value of $100 \%$ in the phylogenetic tree and the lowest temperature for growth of Alishewanella species is significantly higher than that of Rheinheimera species. At the time of writing, there are not enough data to support combination of the two genera. It may be possible to amalgamate the two genera if more strains that are closely related to the two genera are isolated, followed by accumulation of the phylogenetic data. In this study, analysis of 16S rRNA gene sequences and DNA-DNA relatedness data, as well as physiological and biochemical tests, have identified genotypic and phenotypic differences between strain $\mathrm{B} 11^{\mathrm{T}}$ and other species. Taken together, these data clearly differentiate the novel isolate from strains of closely related species. For these reasons, it is concluded that strain $\mathrm{B} 11^{\mathrm{T}}$ represents a novel species of the genus Alishewanella, for which the name Alishewanella aestuarii is proposed.

\section{Emended description of the genus Alishewanella}

Alishewanella (A.li.she.wa.nel'la. L. pron. alius the other; N.L. fem. n. Shewanella a bacterial genus name; N.L. fem. n. Alishewanella the other Shewanella).
The description of the genus is based on that given by Fonnesbech Vogel et al. (2000), with the following amendments. Cells are Gram-negative, motile or non-motile rods. Oxidase- and catalase-positive. The requirement for $\mathrm{NaCl}$ for growth is dependent on the species. Hydrolyse gelatin, but are unable to produce indole, urease, $\beta$ galactosidase or arginine dihydrolase. Do not grow at temperatures of $17{ }^{\circ} \mathrm{C}$ or less. The DNA G $+\mathrm{C}$ content is 49.5-51.0 mol\%. The type species is Alishewanella fetalis.

\section{Description of Alishewanella aestuarii sp. nov.}

Alishewanella aestuarii (aes.tu.a' ri.i. L. gen. n. aestuarii of a tidal flat).

Cells are Gram-negative and motile with a single polar flagellum. Colonies are transparent and round with a diameter of $0.5-1.0 \mathrm{~mm}$ after incubation for 2 days on R2A agar plates at $37{ }^{\circ} \mathrm{C}$. Also grows on TSA, MA, LA and blood agar, but not on NA. Does not require $\mathrm{NaCl}$ for growth but is able to grow in up to $5 \% \mathrm{NaCl}$, with optimal growth at $3 \%(\mathrm{w} / \mathrm{v}) \mathrm{NaCl}$. The temperature range for growth is $18-44{ }^{\circ} \mathrm{C}$ (optimum, $37{ }^{\circ} \mathrm{C}$ ), but no growth occurs at 17 or $45^{\circ} \mathrm{C}$. Catalase- and oxidase-positive. Can reduce nitrate to nitrite and nitrogen. Hydrolyses gelatin, but not starch, aesculin or $p$-nitrophenyl $\beta$-D-galactopyranoside. Negative for indole production, glucose fermentation, arginine dihydrolase and urease. Maltose is assimilated. Glucose, arabinose, mannose, mannitol, $N$-acetylglucosamine, potassium gluconate, capric acid, adipic acid, malate, trisodium citrate and phenylacetic acid are not assimilated. Assays using the API ZYM system are positive for alkaline phosphatase, esterase (C4), esterase lipase (C8), leucine arylamidase, valine arylamidase, cystine arylamidase, tryp$\sin , \alpha$-chymotrypsin, acid phosphatase and naphthol-AS-BIphosphohydrolase. Lipase (C14), $\alpha$-galactosidase, $\beta$-galactosidase, $\beta$-glucuronidase, $\alpha$-glucosidase, $\beta$-glucosidase, $N$ acetyl- $\beta$-glucosaminidase, $\alpha$-mannosidase and $\alpha$-fucosidase activities are not observed. Predominant fatty acids are $\mathrm{C}_{18: 1} \omega 7 c, \mathrm{C}_{17: 1} \omega 8 c$, summed feature $3\left(\mathrm{C}_{16: 1} \omega 7 c\right.$ and/or iso- $\left.\mathrm{C}_{15: 0} 2-\mathrm{OH}\right), \mathrm{C}_{16: 0}$ and $\mathrm{C}_{17: 0}$.

The type strain is $\mathrm{B} 11^{\mathrm{T}}\left(=\mathrm{KCTC} 22051^{\mathrm{T}}=\mathrm{DSM} 19476^{\mathrm{T}}\right.$ ), isolated from tidal flat sediment in Yeosu, Republic of Korea. The genomic DNA G $+\mathrm{C}$ content of the type strain is $49.5 \mathrm{~mol} \%$.

\section{Acknowledgements}

This work was supported by the KRIBB Research Initiative Program, the Environmental Biotechnology National Core Research Center (KOSEF: R15-2003-012-02002-0) and the Conservation Technology Research and Development project hosted by the National Research Institute of Cultural Heritage Administration.

\section{References}

Baker, G. C., Smith, J. J. \& Cowan, D. A. (2003). Review and reanalysis of domain-specific $16 \mathrm{~S}$ primers. J Microbiol Methods 55, 541-555. 
Brettar, I., Christen, R. \& Höfle, M. G. (2006). Rheinheimera perlucida sp. nov., a marine bacterium of the Gammaproteobacteria isolated from surface water of the central Baltic Sea. Int J Syst Evol Microbiol 56, 2177-2183.

Buck, J. D. (1982). Nonstaining (KOH) method for determination of gram reactions of marine bacteria. Appl Environ Microbiol 44, 992-993.

Felsenstein, J. (1981). Evolutionary trees from DNA sequences: a maximum likelihood approach. J Mol Evol 17, 368-376.

Fonnesbech Vogel, B. F., Venkateswaran, K., Christensen, H., Falsen, E., Christiansen, G. \& Gram, L. (2000). Polyphasic taxonomic approach in the description of Alishewanella fetalis gen. nov., sp. nov., isolated from a human foetus. Int J Syst Evol Microbiol 50, 1133-1142.

Kimura, M. (1980). A simple method for estimating evolutionary rates of base substitutions through comparative studies of nucleotide sequences. J Mol Evol 16, 111-120.

Kluge, A. G. \& Farris, J. S. (1969). Quantitative phyletics and the evolution of anurans. Syst Zool 18, 1-32.

Kumar, S., Tamura, K. \& Nei, M. (2004). MEGA3: integrated software for molecular evolutionary genetics analysis and sequence alignment. Brief Bioinform 5, 150-163.

Mesbah, M. \& Whitman, W. B. (1989). Measurement of deoxyguanosine/thymidine ratios in complex mixtures by high-performance liquid chromatography for determination of the mole percentage guanine + cytosine of DNA. J Chromatogr 479, 297-306.

MIDI (1999). Sherlock Microbial Identification System Operating Manual, version 3.0. Newark, DE: MIDI Inc.

Rice, P., Longden, I. \& Bleasby, A. (2000). EmBoss: the European Molecular Biology Open Software Suite. Trends Genet 16, 276-277.

Roh, S. W., Sung, Y., Nam, Y. D., Chang, H. W., Kim, K. H., Yoon, J. H., Jeon, C. O., Oh, H. M. \& Bae, J. W. (2008). Arthrobacter soli sp. nov., a novel bacterium isolated from wastewater reservoir sediment. $J$ Microbiol 46, 40-44.

Romanenko, L. A., Uchino, M., Falsen, E., Zhukova, N. V., Mikhailov, V. V. \& Uchimura, T. (2003). Rheinheimera pacifica sp. nov., a novel halotolerant bacterium isolated from deep sea water of the Pacific. Int J Syst Evol Microbiol 53, 1973-1977.

Saitou, N. \& Nei, M. (1987). The neighbor-joining method: a new method for reconstructing phylogenetic trees. Mol Biol Evol 4, 406425.

Sasser, M. (1990). Identification of bacteria by gas chromatography of cellular fatty acids, MIDI Technical Note 101. Newark: DE: MIDI Inc.

Smibert, R. M. \& Krieg, N. R. (1994). Phenotypic characterization. In Methods for General and Molecular Bacteriology, pp. 607-654. Edited by P. Gerhardt, R. G. E. Murray, W. A. Wood \& N. R. Kreig. Washington, DC: American Society for Microbiology.

Swofford, D. L. (1998). PAUP*: Phylogenetic analysis using parsimony (and other methods), version 4. Sunderland, MA: Sinauer Associates.

Thompson, J. D., Gibson, T. J., Plewniak, F., Jeanmougin, F. \& Higgins, D. G. (1997). The CLUSTAL_X windows interface: flexible strategies for multiple sequence alignment aided by quality analysis tools. Nucleic Acids Res 25, 4876-4882.

Wayne, L. G., Brenner, D. J., Colwell, R. R., Grimont, P. A. D., Kandler, O., Krichevsky, M. I., Moore, L. H., Moore, W. E. C., Murray, R. G. E. \& other authors (1987). International Committee on Systematic Bacteriology. Report of the ad hoc committee on reconciliation of approaches to bacterial systematics. Int $J$ Syst Bacteriol 37, 463-464.

Yoon, J. H., Bae, S. E., Kang, S. J. \& Oh, T. K. (2007). Rheinheimera aquimaris sp. nov., isolated from seawater of the East Sea in Korea. Int J Syst Evol Microbiol 57, 1386-1390. 